J. Dairy Sci. 92:4239-4248

doi:10.3168/jds.2008-1751

(c) American Dairy Science Association, 2009.

\title{
Microbiological quality of bulk tank raw milk in Prince Edward Island dairy herds
}

\author{
A. M. Elmoslemany, ${ }^{*} \dagger$ G. P. Keefe,${ }^{*} \ddagger^{1}$ I. R. Dohoo, ${ }^{*} \S$ and R. T. Dingwell\# \\ *Department of Health Management, University of Prince Edward Island, Charlottetown, PEI, C1A 4P3, Canada \\ †Department of Hygiene and Preventive Medicine, Faculty of Veterinary Medicine, Kafrelsheikh University, Egypt, PO Box 33516 \\ $\ddagger$ Maritime Quality Milk, and \\ §Centre for Veterinary Epidemiological Research, University of Prince Edward Island, Charlottetown, PEI, C1A 4P3, Canada \\ \#Holdrege Vet Clinic PC, Holdrege, NE 68949
}

\section{ABSTRACT}

The objectives of this study were to evaluate microbiological quality of bulk tank milk in Prince Edward Island, to evaluate correlation among milk quality criteria, and to determine seasonal effects on milk quality parameters. Bulk tank raw milk quality was evaluated on all Prince Edward Island dairy herds $(\mathrm{n}=235)$ over a 2-yr period (March 2005 to March 2007). Biweekly total aerobic (TAC), preliminary incubation (PIC), laboratory pasteurization, and coliform (CC) counts were determined using a Petrifilm culture system. Additionally, bulk tank somatic cell count was determined weekly. The mean and median values were $12.8 \times 10^{3}$ and $4.9 \times 10^{3} \mathrm{cfu} / \mathrm{mL}$ for TAC, $29.6 \times 10^{3}$ and 13 $\times 10^{3} \mathrm{cfu} / \mathrm{mL}$ for PIC, 87 and $12 \mathrm{cfu} / \mathrm{mL}$ for laboratory pasteurization count, 21 and $5 \mathrm{cfu} / \mathrm{mL}$ for CC, and $218 \times 10^{3}$ and $187 \times 10^{3}$ cells $/ \mathrm{mL}$ for somatic cell count. There was moderate correlation $(0.57)$ between TAC and PIC. All other correlation coefficients were low $(<0.26)$. Correlation results suggest that a single quality parameter could not predict others used in this study. Seasonal data indicate that 1) in general, all counts tended to be low in winter, 2) the CC and somatic cell count were always high in summer, and 3 ) TAC tended to be high during summer.

Key words: bulk tank milk, somatic cell, microbiological quality

\section{INTRODUCTION}

Bacteria in raw milk can affect the quality, safety, and consumer acceptance of dairy products. Several human microbial pathogens such as Listeria monocytogenes, Salmonella spp., Staphylococcus aureus, Campylobacter jejuni, and Mycobacterium tuberculosis have been found to be associated with milk and milk products (Flowers

Received September 25, 2008.

Accepted May 19, 2009.

${ }^{1}$ Corresponding author: gkeefe@upei.ca et al., 1993; Jayarao et al., 2006). Even for organisms that are not pathogenic, there can be effects on quality. For example, high microbial counts in raw milk are responsible for quality defects in pasteurized milk, UHT processed milk, dried skim milk, butter, and cheese (Sørhaug and Stepaniak, 1997; Barbano et al., 2006). Additionally, selecting raw milk of high quality has been associated with a decrease in consumer complaints caused by fluid milk quality (Keefe and Elmoslemany, 2007). As a result, many countries have milk quality regulations, including limits on the total number of bacteria in raw milk, to ensure the quality and safety of the final product.

Microbiological quality of bulk tank milk (BTM) is measured by means of several tests including, total aerobic count (TAC), preliminary incubation count (PIC), laboratory pasteurization count (LPC), and coliform count $(\mathbf{C C})$. The TAC is a recognized alternative and is considered equivalent to the standard plate count (SPC; Wehr and Frank, 2004). The TAC provides an estimate of the total number of aerobic bacteria present in raw milk. This measure does not provide information about specific hygienic failure or the identity of specific microbial groups in the milk; it indicates changes in the production, collection, handling, and storage environment (Chambers, 2002). The PIC measures the number of psychrotrophic or coldloving bacteria that grow at elevated refrigeration temperature. The PIC is generally higher than the TAC, and a PIC 3 times greater than the TAC is considered significantly elevated (Murphy, 1997). The LPC quantifies the number of thermoduric bacteria that survive laboratory pasteurization at $62.8^{\circ} \mathrm{C}$ for $30 \mathrm{~min}$. This process kills most bacteria present in milk, including mastitis-causing bacteria and zoonotic pathogens; however, certain species may survive in low numbers. These surviving bacteria may cause off-flavors and reduced shelf life of dairy products. The number of coliforms in milk is an indicator of the cleanliness of cows and their environment (Murphy, 1997; Jayarao and Wolfgang, 2003). Bulk tank somatic cell count (BTSCC) is an 
indicator of the level of subclinical mastitis present in a herd. Milk with high BTSCC has a higher level of proteolytic and lipolytic enzymes, which reduce cheese production and affect the flavor and shelf life of dairy products (Barbano et al., 2006).

With the exception of SPC (or its alternative, TAC) and BTSCC, these tests were not routinely performed in Prince Edward Island (PEI). As part of a program to improve raw milk quality, the industry wanted to establish benchmark values on a province-wide basis to determine current levels for each test. Additionally, literature regarding seasonal effects on microbial quality of BTM is scarce, so the objectives of this study were 1) determination of the current bacteriological quality of BTM in PEI dairy herds using several quality parameters, 2) evaluation of correlations among quality parameters, and 3) investigation of seasonal variations in BTM quality parameters.

\section{MATERIALS AND METHODS}

\section{Data Collection}

Bulk tank milk samples were collected from all PEI dairy herds $(\mathrm{n}=235)$ over a 2 -yr period (March 2005 to March 2007). Raw milk samples were collected from $50 \%$ of herds on alternating weeks, so that each herd was sampled approximately every 2 wk. Samples were collected in 30-mL sterile screw-cap tubes (Starplex Scientific Inc., Etobicoke, Ontario, Canada) by trained milk haulers and held on ice until arrival at the laboratory. All microbiological analyses were performed within $36 \mathrm{~h}$ of pick up at the farm.

\section{Herd Demographic Data}

The average herd size and production of PEI dairy herds was recently reported to be 60 cows and 8,894 $\mathrm{kg} /$ cow per year, respectively (Olde Riekerink et al., 2006). Herds in this study were similar in herd size (58 cows/herd). In this study, lactating cows were housed in tie stall $(60 \%)$, free stall $(27 \%)$, or straw pack $(13 \%)$. Additionally, $66 \%$ of the farms had a pipeline milking system, $29 \%$ had a milking parlor, and 5\% used bucket milking systems. In $74 \%$ of farms, cows had access to pasture during summer; in $13 \%$, cows had access only to an exercise yard; and in $13 \%$, cows were confined year round.

\section{Bacteriological Analysis of BTM}

Bulk tank milk samples were examined for TAC, PIC, LPC, and CC using Petrifilm (3M Canada, London, Ontario, Canada). Milk samples were mixed thoroughly by vortexing. For TAC and PIC, 1/100 dilution was used. For LPC and CC, $1 \mathrm{~mL}$ of milk was cultured directly on Petrifilm. The TAC, LPC, and CC were conducted according to Standard Methods for the Examination of Dairy Products (Wehr and Frank, 2004). The PIC was performed as described by Richardson (1985). Plates for enumeration of TAC, PIC, and LPC were incubated at $32^{\circ} \mathrm{C}$ for $48 \mathrm{~h}$. Plates for CC were incubated at $32^{\circ} \mathrm{C}$ for $24 \mathrm{~h}$. All plates were read using an automated counter (3M Petrifilm Plate Reader, 3M Canada) and data were stored in Excel spreadsheets (Microsoft, Seattle, WA) before merging into the database. The maximum reading by the automated reader is ">999," which corresponds to a minimal bacterial load of 100,000 in the case of TAC and PIC, and 1,000 in the case of LPC and CC. All plate counts were expressed as the number of colony-forming units per milliliter. In addition to bacterial count, SCC was evaluated weekly using a CombiFoss 4000 or CombiFoss 6000 FC (Foss Electric, Hillerød, Denmark).

\section{Statistical Analysis}

Data were collected on spreadsheets and merged into a single database using Stata version 10 (Stata Corp., 2007). Summary statistics, frequency distributions, and Spearman rank correlations were computed on raw data. The geometric mean was presented instead of arithmetic mean because all 5 milk quality parameters had strongly right-skewed distributions. Each count was divided into intervals based on quality result thresholds to illustrate the distribution and to allow comparison of the results with other studies that used similar testing. Thresholds for high bacterial counts were selected based on suggested guidelines by Murphy (1997). The bonus threshold was determined by local industry, based on average bacterial and SCC counts over a 3-mo period. The consistency of the results within herds was evaluated by calculation of the coefficient of variation (CV) for each test within herds after natural logarithmic transformation of all counts. The $\mathrm{CV}$ is the ratio of the standard deviation to the mean. For seasonal variation, BTM samples were divided into 4 seasons by study year: spring (March 21 to June 20), summer (June 21 to September 20), fall (September 21 to December 20), and winter (December 21 to March 20). Study year 1 started on March 21, 2005, and completed March 20, 2006; study year 2 extended from March 21, 2006, to March 27, 2007. A graph showing the median monthly count over the 2 -yr study period was presented for each quality parameter. Statistical significance of season effects were evaluated using linear mixed models with herd random effects and autoregressive correlation structure for the repeated measures on herds (TAC, 
Table 1. Frequency distributions of total aerobic, preliminary incubation, laboratory pasteurization, coliform, and somatic cell counts of bulk tank milk samples in Prince Edward Island, Canada ${ }^{1}$

\begin{tabular}{lrrrrrrr}
\hline Parameter $^{2}$ & $10 \%$ & \multicolumn{1}{c}{$25 \%$} & $50 \%$ & $75 \%$ & $90 \%$ & Mean & Geometric mean \\
\hline TAC & 1,000 & 2,100 & 4,900 & 13,000 & 34,000 & 12,800 & 5,300 \\
PIC & 1,500 & 3,800 & 13,000 & 47,000 & 100,000 & 29,600 & 12,000 \\
LPC & 1 & 4 & 12 & 32 & 100 & 87 & 16 \\
CC & 0 & 1 & 5 & 17 & 54 & 21 & 8 \\
SCC & 84,000 & 122,000 & 187,000 & 282,000 & 387,000 & 218,000 & 184,000 \\
\hline
\end{tabular}

${ }^{1}$ Bacterial counts were expressed in colony-forming units per milliliter $(\mathrm{cfu} / \mathrm{mL})$.

${ }^{2} \mathrm{TAC}=$ total aerobic count; PIC $=$ preliminary incubation count; $\mathrm{LPC}=$ laboratory pasteurization count; $\mathrm{CC}=$ coliform count.

PIC, and SCC) and generalized estimating equations with binomial distributions, a logit link, and an autoregressive correlation (LPC and CC).

\section{RESULTS}

\section{Descriptive Statistics}

A total of 11,099 BTM samples were evaluated for each of TAC, PIC, LPC, and CC, and 22,714 samples for SCC. Table 1 and Figure 1 show summary statistics and frequency distribution for each of the bacterial parameters and SCC. For all 5 parameters, the mean count was larger than the median, indicating a rightskewed distribution. A comparative summary of the results of this study and other studies using similar testing is presented in Table 2 .

In most milk samples, bacterial counts were either below the regulatory levels for the province or below the threshold for high levels recommended by previous literature. Approximately $6 \%$ of TAC samples were above the regulatory limit for total bacterial count $(50,000 \mathrm{cfu} / \mathrm{mL})$. For PIC, $23 \%$ of the samples were considered high $(>50,000 \mathrm{cfu} / \mathrm{mL})$. About $8 \%$ of LPC samples and $11 \%$ of CC samples exceeded the threshold for high count of 200 and $50 \mathrm{cfu} / \mathrm{mL}$, respectively. Finally, $3.9 \%$ of milk samples were above the regulatory limit for SCC in the province $(500,000$ cells $/ \mathrm{mL})$.

\section{Correlation Between Milk Quality Parameters}

The correlation coefficients between milk quality parameters are shown in Table 3. All parameters had positive correlation; however, the highest correlation was between TAC and PIC (0.57) and the lowest correlation was between PIC and SCC (0.08). All other correlation coefficients were low $(<0.26)$.

\section{Coefficient of Variation for Milk Quality Parameters}

The result of the coefficient of variation for each of the quality parameters is shown in Table 4 . The lowest variation was in SCC (0.03), whereas the highest variation was in CC (0.50). Additionally, for all quality parameters the coefficient of variation decreased with the increase in the mean count (Figure 2).

\section{Seasonal Variation}

In general, the average ambient temperature was not different between the 2 study years and was $6.8,18.0$, 6.0 , and $-3.6^{\circ} \mathrm{C}$ for spring, summer, fall, and winter, respectively (Table S1, available online: http://jds.fass. org/content/vol92/issue9/). Overall, there was a significant effect of season on each of the quality parameters $(P<0.001)$. In addition, there was a difference $(P<$ 0.001 ) between year 1 and year 2 for TAC and SCC. The interaction between season and year was significant $(P<0.05)$ for all quality parameters except LPC $(P=$ $0.28)$ and SCC $(P=0.38$; Tables S2-S6, available online: http://jds.fass.org/content/vol92/issue9/). Figure 3 shows the median count per month for different milk quality parameters over the 2-yr study period.

In year 1, the TAC was mainly high during summer months, whereas in year 2 , higher counts were observed during summer and fall. The 75th percentile for TAC was highest in September of year $2(24,000 \mathrm{cfu} / \mathrm{mL})$. The median PIC was highest during April in year 1, whereas the median was highest during November in year 2 . The 75 th percentile for PIC was highest during November year $2(89,000 \mathrm{cfu} / \mathrm{mL})$.

For LPC, in year 1 , the median was highest during summer and fall months, whereas in year 2 , the median LPC was approximately the same among seasons. The highest 75 th percentile was observed during September of year $1(60 \mathrm{cfu} / \mathrm{mL})$. For CC and SCC, the median count was highest during summer months compared with other seasons. For CC, the 75th percentile was highest in August of year 1 ( $38 \mathrm{cfu} / \mathrm{mL})$. For SCC, the 75th percentile was highest in July of year $2(322,000$ cells $/ \mathrm{mL}$ ). In general, all counts tended to be lower in winter months.

\section{DISCUSSION}

Because high-quality dairy products start with high-quality raw milk, there are continuing demands 


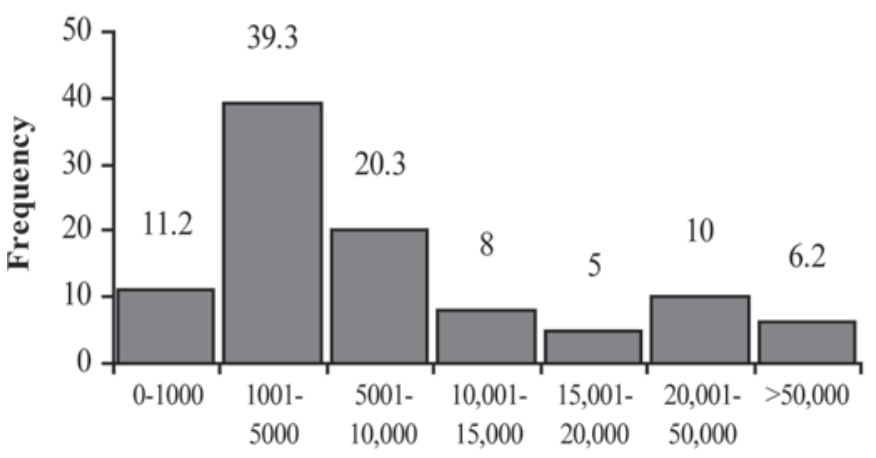

TAC categories
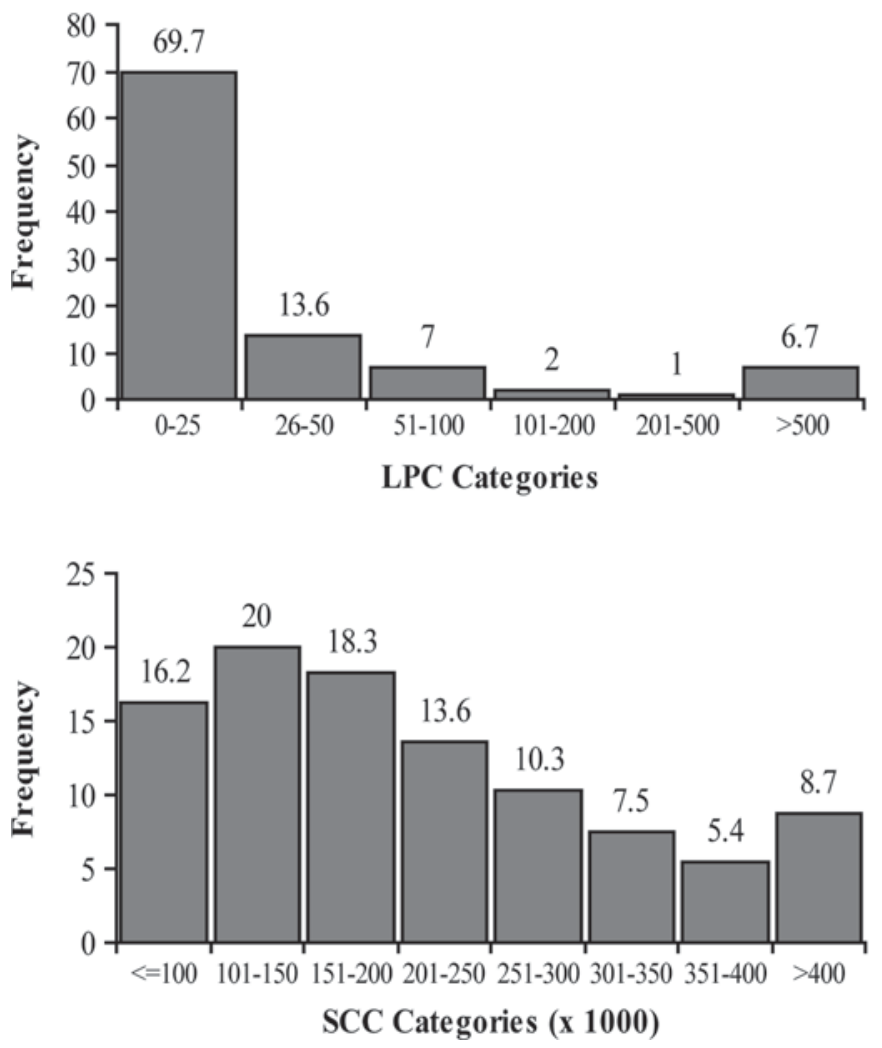

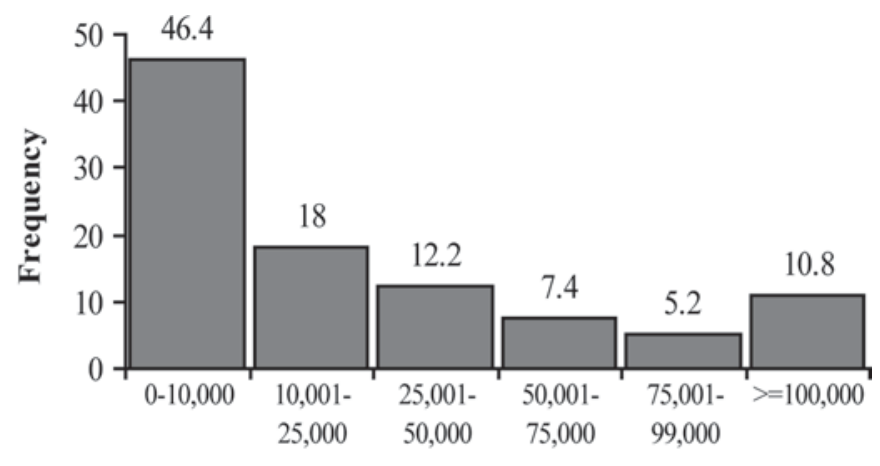

PIC categories

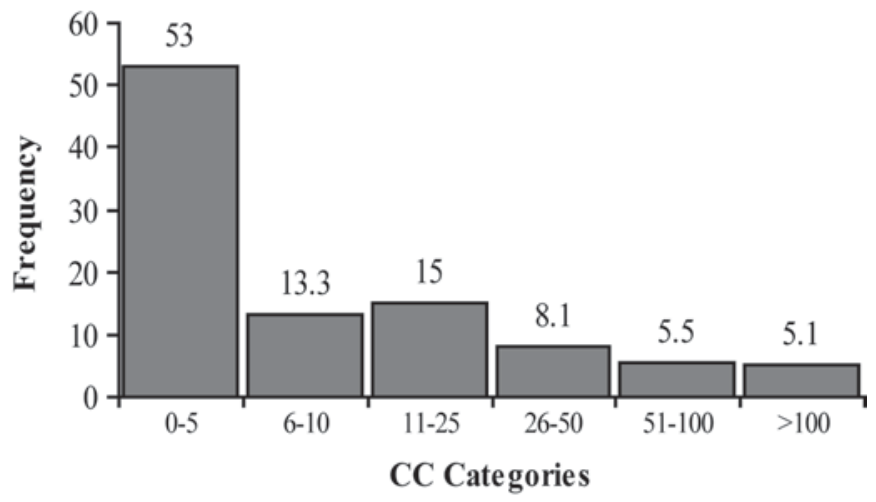

Figure 1. Frequency distributions of total aerobic count (TAC), preliminary incubation count (PIC), laboratory pasteurization count (LPC), coliform count (CC) and SCC of bulk tank milk samples in Prince Edward Island, Canada. Percentages are displayed at the top of each interval. Bacterial counts were expressed in colony-forming units per milliliter.

upon producers to improve their raw milk bacteria and BTSCC numbers. Many processors provide incentive programs to encourage dairy farmers to produce milk with lower bacteria and BTSCC than the required regulatory limits. The TAC and SCC are the only regulatory tests among the 5 parameters used in this study; however, they do not give a full assessment of the hygienic quality of raw milk. Therefore, many industries use several tests to assess raw BTM quality. In this study, 5 criteria were used: TAC, PIC, LPC, CC, and SCC.

\section{Descriptive Statistics}

Data in this study were compared with 2 studies that had used similar testing procedures. The first study, by Boor et al. (1998), was based on 855 BTM samples from randomly selected farms in New York State that represent about $10 \%$ of all dairy farms in the state. Data on herd size and management practices were not available from this study. The second study, by Jayarao et al. (2004), was based on 126 dairy herds with an average herd size of 87 cows per herd. Volunteer herds 
Table 2. Comparison of bulk tank milk quality parameters among different studies

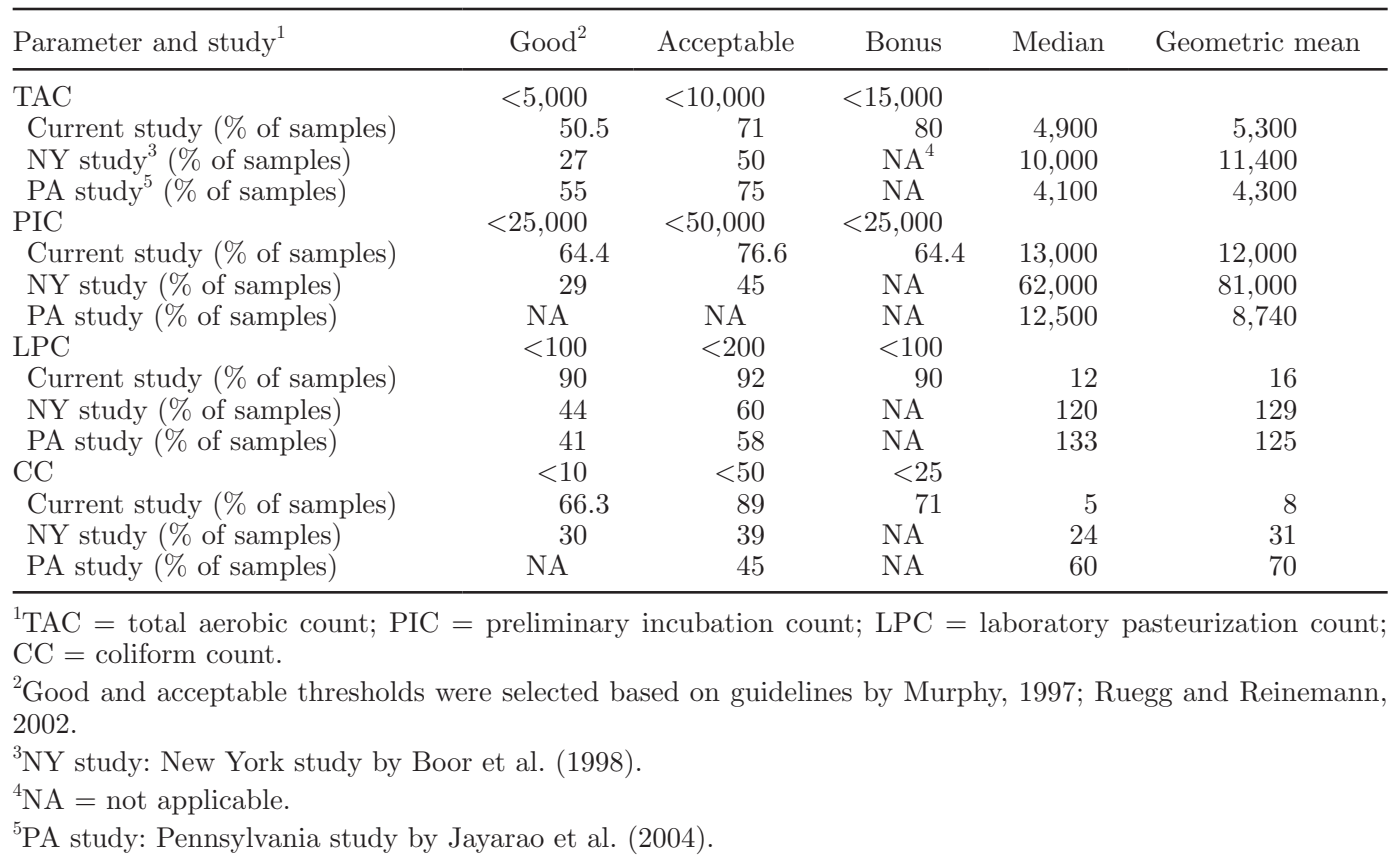

were solicited from 12 counties in Pennsylvania. For most of these herds, cows were milked twice a day $(88 \%)$ in stanchion barns $(61 \%)$ or parlors $(39 \%)$.

TAC. The TAC (an alternative to SPC) is an indicator of the general hygienic condition during milk production and storage. A count of $<5,000 \mathrm{cfu} / \mathrm{mL}$ indicates proper hygiene, and a count of $<10,000 \mathrm{cfu} /$ $\mathrm{mL}$ should be achievable by most farms (Murphy, 1997; Jayarao and Wolfgang, 2003). In our study approximately $50 \%$ of the samples were $<5,000 \mathrm{cfu} / \mathrm{mL}$ and $71 \%$ were $<10,000 \mathrm{cfu} / \mathrm{mL}$. The percentage of herds achieving low bacteria levels was much higher than those reported by Boor et al. (1998) in New York State and somewhat lower than those reported by Jones and Sumner (1999) in Virginia and by Jayarao et al. (2004) in Pennsylvania (Table 2). Additionally, previous studies in the United States reported variation in geometric mean SPC that ranged from 4,700 to $17,000 \mathrm{cfu} / \mathrm{mL}$ (Peeler et al., 1989; Boor et al., 1998). Our geometric

Table 3. Spearman rank correlation among total aerobic, preliminary incubation, laboratory pasteurization, coliform, and somatic cell counts of bulk tank milk samples in Prince Edward Island, Canada

\begin{tabular}{llllll}
\hline Parameter $^{1}$ & TAC & PIC & LPC & CC & SCC \\
\hline TAC & 1.000 & & & & \\
PIC & 0.574 & 1.000 & & & \\
LPC & 0.158 & 0.130 & 1.000 & & \\
CC & 0.217 & 0.200 & 0.158 & 1.000 & \\
SCC & 0.165 & 0.085 & 0.253 & 0.157 & 1.000 \\
\hline
\end{tabular}

${ }^{1} \mathrm{TAC}=$ total aerobic count; PIC $=$ preliminary incubation count; $\mathrm{LPC}=$ laboratory pasteurization count; $\mathrm{CC}=$ coliform count. mean $(5,300 \mathrm{cfu} / \mathrm{mL})$ was close to the lower end of the range reported in these studies. The right tail of our data was truncated at 100,000 for both TAC and PIC, which will affect mean counts (lower) but not percentiles. These variations in SPC among different regions indicate that it can be influenced by geographical area and different management practices.

$\boldsymbol{P I C}$. The PIC is used to estimate the number of psychrotrophic bacteria in raw milk. An acceptable PIC count should be $<50,000 \mathrm{cfu} / \mathrm{mL}$ and not more than 3 to 4 times the SPC (Murphy, 1997); a desirable PIC count is $<25,000 \mathrm{cfu} / \mathrm{mL}$ (Jones and Sumner, 1999). In our study, approximately 64 and $77 \%$ of the samples had PIC $<25,000$ and 50,000 cfu/mL, respectively. The percentage of herds achieving good or acceptable PIC levels was 35 and 32 percentage points higher, respectively, than those reported by Boor et al. (1998). In this study, $16 \%$ of the samples with PIC $>50,000$ had PIC

Table 4. The percentiles of the coefficient of variation for different milk quality parameters

\begin{tabular}{lcccc}
\hline Parameter $^{1}$ & Mean $^{2}$ & $25 \%$ & $50 \%$ & $75 \%$ \\
\hline TAC & 0.15 & 0.12 & 0.14 & 0.17 \\
PIC & 0.16 & 0.13 & 0.15 & 0.18 \\
LPC & 0.42 & 0.32 & 0.42 & 0.49 \\
CC & 0.50 & 0.42 & 0.50 & 0.58 \\
SCC & 0.03 & 0.02 & 0.03 & 0.04 \\
\hline
\end{tabular}

${ }^{1} \mathrm{TAC}=$ total aerobic count; PIC $=$ preliminary incubation count; $\mathrm{LPC}=$ laboratory pasteurization count; $\mathrm{CC}=$ coliform count.

${ }^{2} \mathrm{Mean}$ coefficient of variation of all herds. 


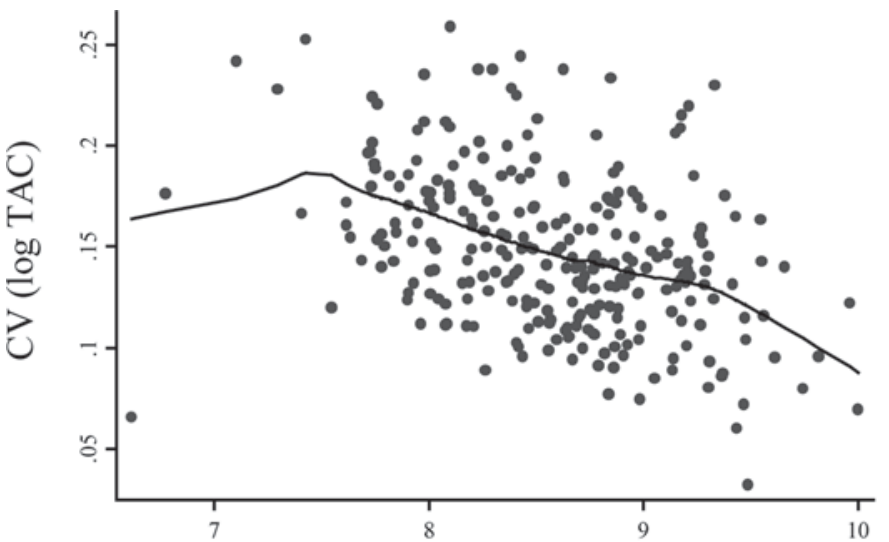

Herd mean $(\log \mathrm{TAC})$
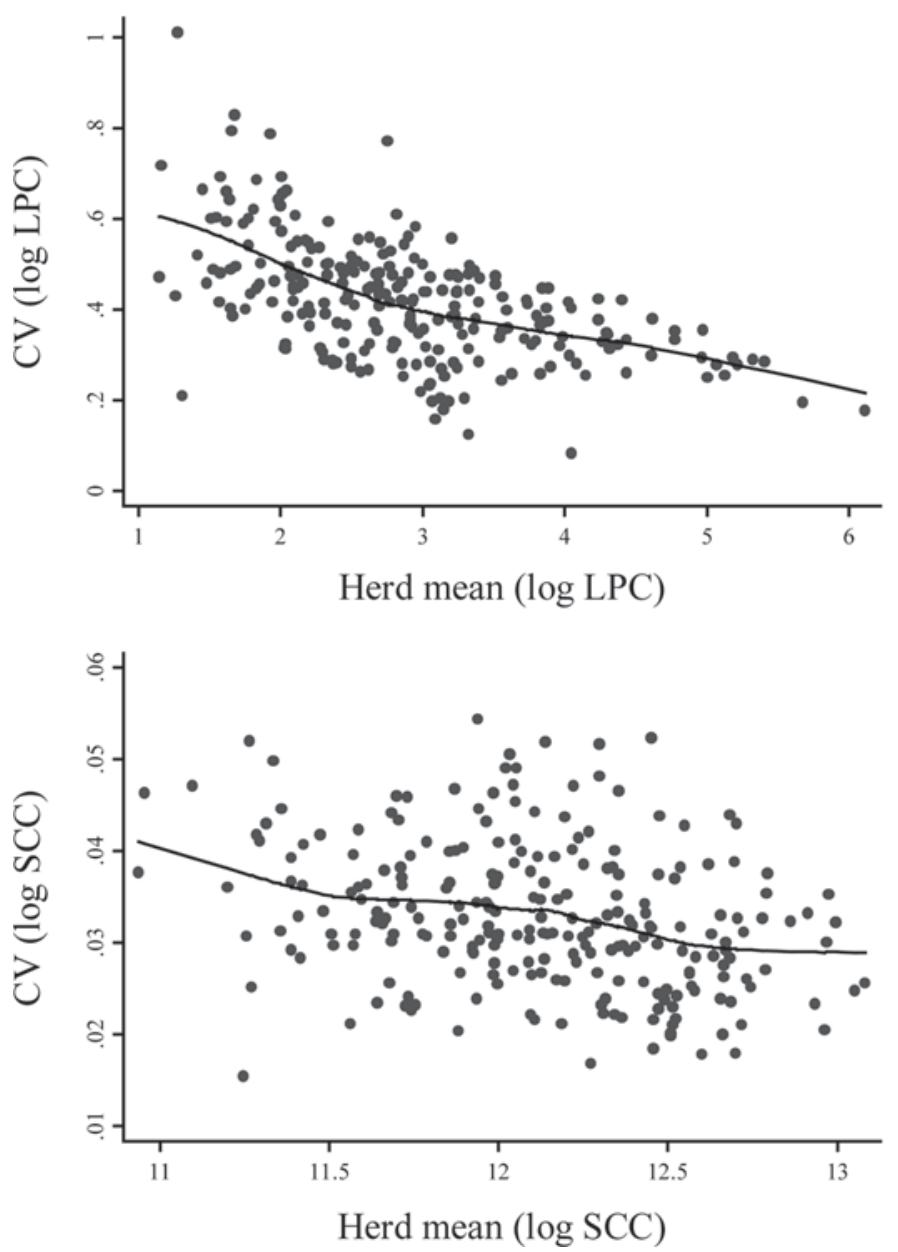
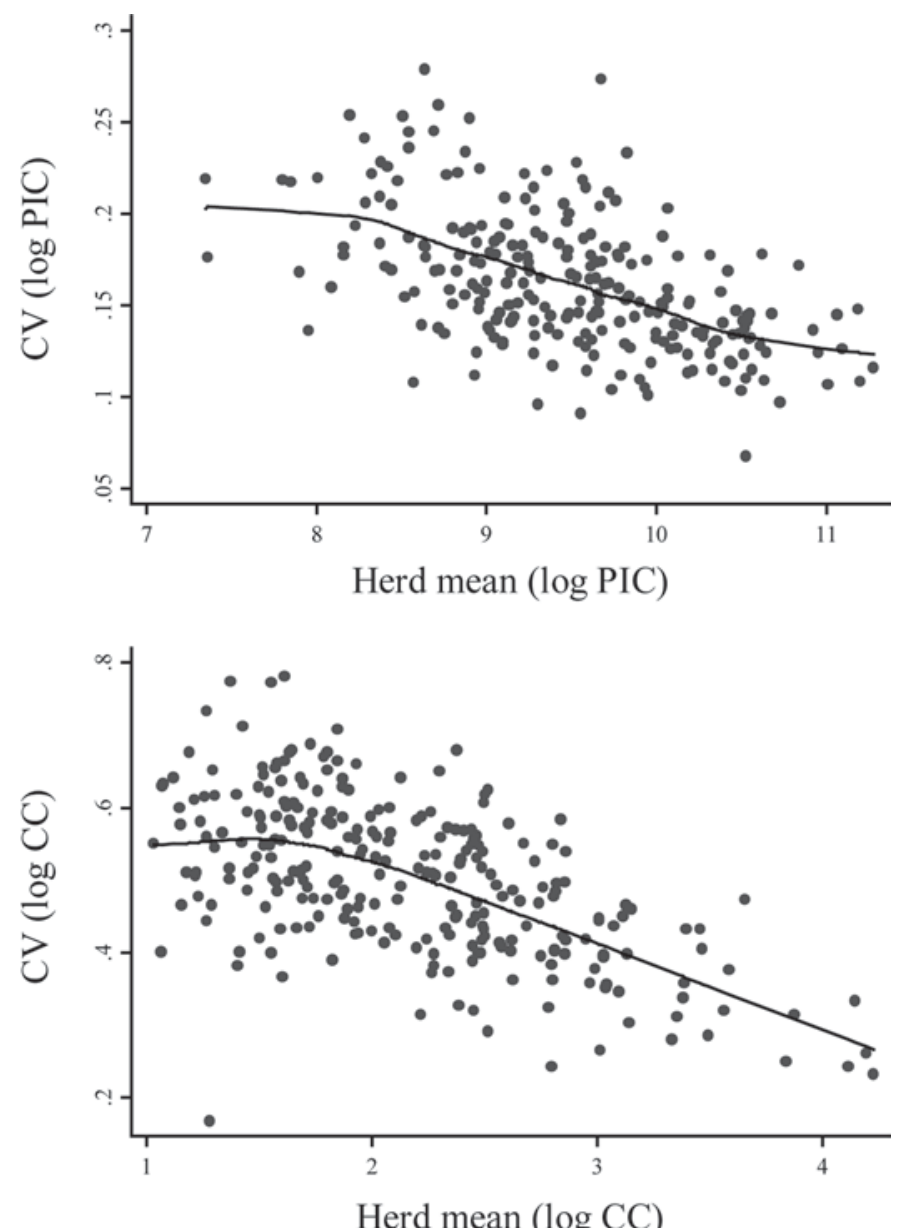

Figure 2. The relationship between coefficient of variation and mean herd count for total aerobic count (TAC), preliminary incubation count (PIC), laboratory pasteurization count (LPC), coliform count (CC), and SCC. The smoothed lines show the direction of the relationship between coefficient of variation and mean herd count.

3 or more times higher than TAC, indicating a high psychrotroph burden. Our geometric mean for PIC was also much lower than that reported in New York State and was in the lower range reported by Peeler et al. (1989) in the multi-state study. Generally, high levels of psychrotrophic bacteria in raw milk will contribute significant quantities of heat-stable proteases and lipases that will break down protein and fat after pasteurization (Sørhaug and Stepaniak, 1997) and cause spoilage of the final product during storage. 


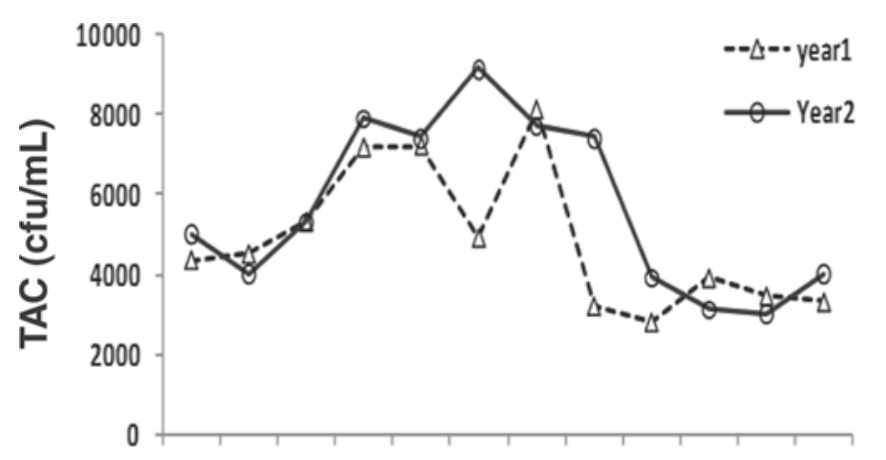

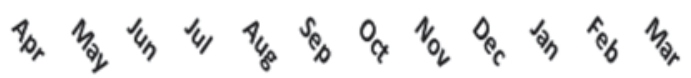

Month

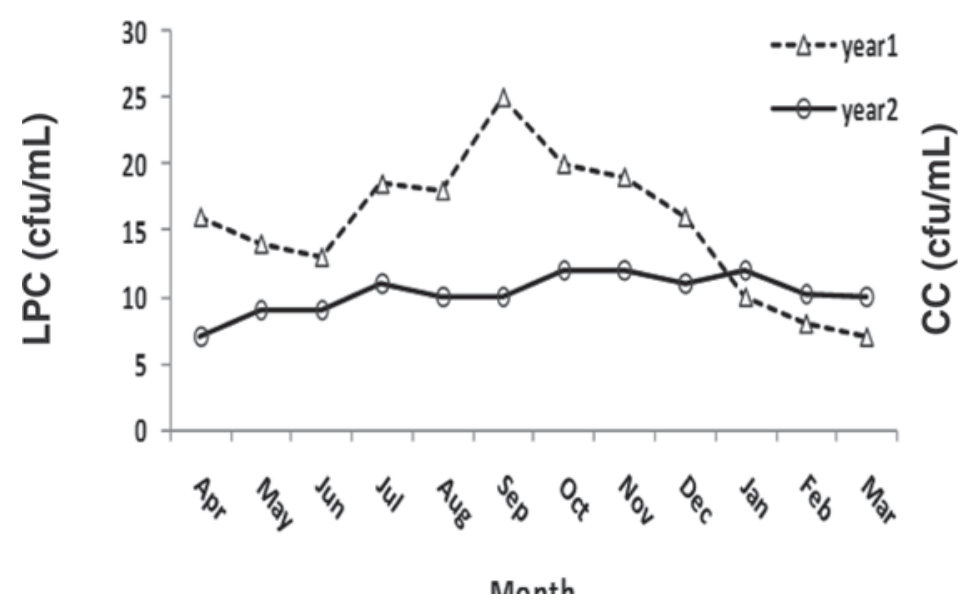

Month

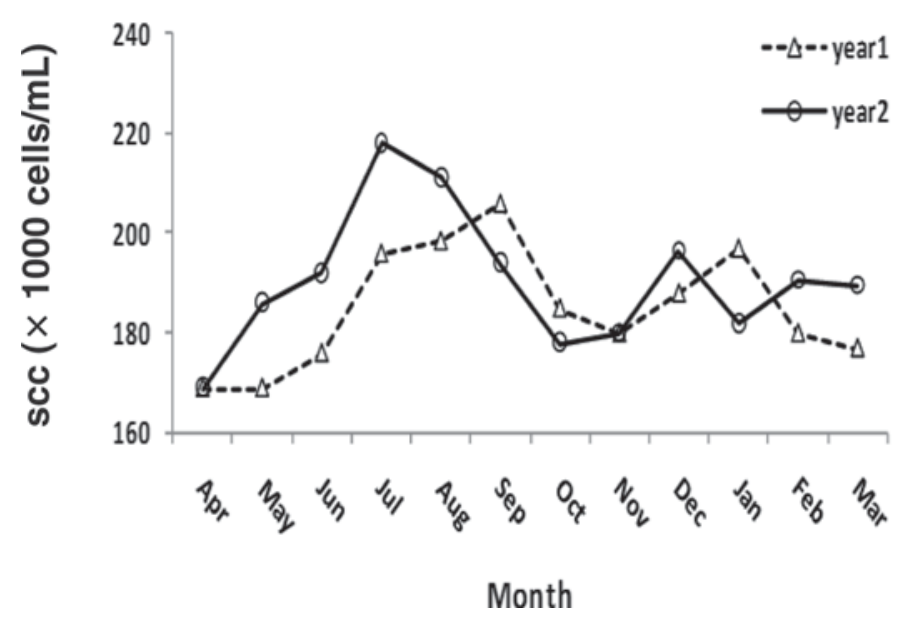

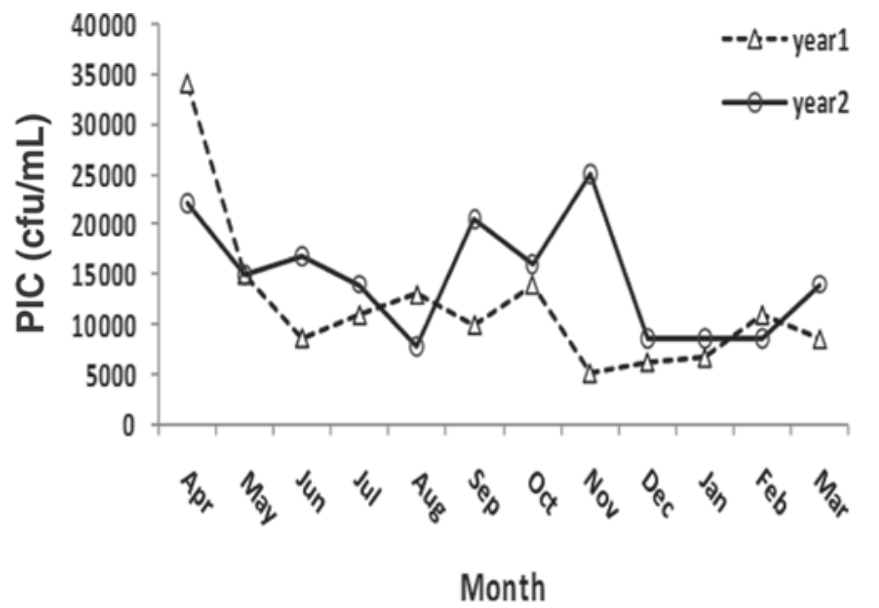

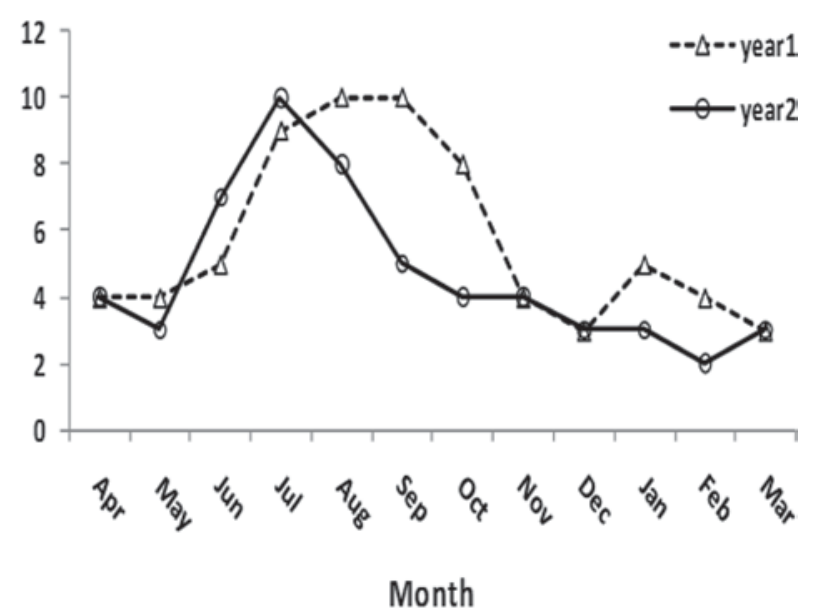

Figure 3. The median total aerobic count (TAC), preliminary incubation count (PIC), laboratory pasteurization count (LPC), coliform count (CC), and SCC of bulk tank milk samples for each month by study year.

LPC. The LPC identifies thermoduric bacteria that can survive exposure to pasteurization temperatures. A count between 100 and $200 \mathrm{cfu} / \mathrm{mL}$ indicates adequate cleaning and sanitation of the milking system, and a count of $<10 \mathrm{cfu} / \mathrm{mL}$ indicates excellent equipment hygiene (Ruegg and Reinemann, 2002). The majority of our samples $(90 \%)$ were $<100 \mathrm{cfu} / \mathrm{mL}$, whereas in New York State, only $44 \%$ of BTM samples were $<100$ $\mathrm{cfu} / \mathrm{mL}$. Additionally, the geometric mean and the median LPC reported in this study were also lower than 
those reported in New York State and in Pennsylvania. Again, our data were right truncated at 1,000, which will give a lower mean but does not influence the percentiles. High thermoduric counts in bulk tank milk are mainly associated with the presence of heat-tolerant bacteria on milking equipment (Murphy, 1997; Ruegg and Reinemann, 2002).

$\boldsymbol{C C}$. Coliforms are used as indicators of unsanitary production practices. A count of $<50 \mathrm{cfu} / \mathrm{mL}$ is considered acceptable. In our study, $89 \%$ of BTM samples were $<50 \mathrm{cfu} / \mathrm{mL}$, whereas in New York and Pennsylvania milk samples, 39 and $45 \%$ had counts of $<50 \mathrm{cfu} / \mathrm{mL}$, respectively. Additionally, our median and geometric mean CC were lower than those reported in New York and Pennsylvania.

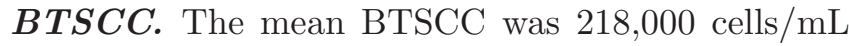
(geometric mean of 184,000 cells $/ \mathrm{mL}$ ), and $50 \%$ of the samples were $<187,000$ cells $/ \mathrm{mL}$. In Ontario, Sargent et al. (1998) reported a mean BTSCC of 250,000 cells/ $\mathrm{mL}$. According to the Canadian Dairy Commission, the mean BTSCC in Canadian provinces in 2006 ranged from 155,000 cells/mL (British Columbia) to 268,000 cells/mL (Saskatchewan) with PEI ranked third (221,000 cells/mL) after British Columbia and Alberta (CDC, 2009). In the United States, the average BTSCC was 363,000 cells $/ \mathrm{mL}$ in New York State (Van Schaik et al., 2002), whereas in Pennsylvania the mean BTSCC was 315,000 cells/mL and the median was 348,000 cells/ mL (Jayarao et al., 2004).

Recently published BTSCC data from outside North America indicate that the geometric mean BTSCC in Ireland in 2004 was approximately 251,000 cells $/ \mathrm{mL}$ (Berry et al., 2006) whereas in Norway the geometric mean was 115,000 cells/ mL (Østerås and Sølverød, 2005).

Ma et al. (2000) reported that high-SCC raw milk had more lipolysis and proteolysis than low-SCC raw milk. They also indicated that higher enzymatic activity in high-SCC raw milk affected the quality of pasteurized fluid milk by accelerating the development of sensory defects such as rancidity and bitterness.

In general, bacterial counts reported in this study were lower than those reported in New York State and Pennsylvania (Boor et al., 1998; Jayarao et al., 2004) and were in the lower end of the range reported by Peeler et al. (1989) in the study that involved 11 states. Additionally, the mean BTSCC reported here was lower than the means reported in the United States (Van Schaik et al., 2002; Jayarao et al., 2004) and Ireland (Berry et al., 2006) and higher than the mean reported in Norway (Østerås and Sølverød, 2005). These variations may be attributed to geographical area and the use of different management practices (Allore et al., 1997).

\section{Correlation Between Quality Parameters}

The TAC was moderately correlated with the PIC (0.57). The correlation between other quality parameters was low $<0.26$. Boor et al. (1998) reported low to moderate correlations between various quality parameters; for example, the correlation coefficient between SPC and PIC was 0.58 in their study. In addition, the correlation between SCC and different bacterial count was low. This was also similar to that reported by Jayarao et al. (2004). The weak correlations reported in this study and previous studies suggest that each count gives different information in relation to management practices and sources of bacterial contamination. It also substantiates the conclusion by other authors that one bacterial test could not be used to estimate other tests (Villar et al., 1996; Boor et al., 1998).

\section{CV for Milk Quality Parameters}

The CV varied widely among milk quality parameters. The values of the CV indicate reasonable consistency of the results for SCC, moderate variation in TAC and PIC, and high variability in LPC and CC. Some of the variation in test results could be attributed to seasonal effects and changes in management practices during the study. However, overall, the relatively high CV indicate that herd assessments should not rely on a single measurement.

\section{Seasonal Variations}

The results regarding seasonal variation showed that there was no consistent seasonal pattern over the 2-yr study period for TAC, PIC, and LPC; however, these quality parameters tended to have low median counts during winter. On the other hand, coliform and SCC counts were highest during the summer in both years. High SCC and total bacterial counts during summer months were reported in the United States (Van Schaik et al., 2002; Helgren and Reinemann, 2003).

Our findings for TAC and SCC were generally in agreement with these results; however, in our study, the TAC showed a second peak during September and November of year 2. There was no significant difference in the average daily temperature or mean daily precipitation between year 1 and year 2 during September and November. (See Table S1, available online: http://jds. fass.org/content/vol92/issue9/).

In Ontario, Schukken et al. (1992) and Sargeant et al. (1998) reported a significant seasonal pattern for SCC, in which the lowest mean occurred in April and the highest mean occurred in October; however, there was no clear seasonal effect for total bacterial count. 
Our SCC data agree with the previous findings where the lowest median SCC was observed in April; however, our data showed that the highest median SCC was observed somewhat earlier in August and September. In Ireland, Berry et al. (2006) reported higher SCC and total bacterial counts during fall and winter and lower counts during spring. They related their finding to the seasonal calving system in Ireland. Soler et al. (1995) reported higher total bacterial, psychrotrophic, thermoduric, and coliform counts in summer and lower counts in winter. Similar results were observed earlier by Jones et al. (1971), who indicated that higher summer temperatures might allow the growth of thermoduric and coliform bacteria on milking equipment especially under improper cleaning and sanitation of milking equipment. Our counts were in agreement with the previous results with regard to occurrence of lower counts in winter; however, high counts did not follow a consistent pattern for PIC and LPC. The different effects of some of the seasons over the 2 years may suggest that the effect of season may be influenced by other farm management practices.

\section{CONCLUSIONS}

The results of this study provide insight into the current state of microbiological quality of BTM milk in PEI. Most samples tested for milk quality parameters were below the regulatory limits of the province (TAC and SCC) or the acceptable limits suggested by the literature (PIC, LPC, and CC). The weak correlation among these parameters indicates differences in onfarm sources for each test and lack of predictive ability among tests. The study also indicates that seasonal effects may be attributed to changes in management practices.

\section{ACKNOWLEDGMENTS}

The authors acknowledge the technical support of T. Andrews, R. Milton, and L. Dalziel (Department of Health Management, Atlantic Veterinary College). This research was funded by Dairy Farmers of Prince Edward Island, Agricultural Research Investment Fund (PEI Department of Agriculture), Purity Dairy, and Amalgamated Dairies Limited.

\section{REFERENCES}

Allore, H. G., P. A. Oltenacu, and H. N. Erb. 1997. Effects of season, herd size, and geographic region on the composition and quality of milk in the northeast. J. Dairy Sci. 80:3040-3049.

Barbano, D. M., Y. Ma, and M. V. Santos. 2006. Influence of raw milk quality on fluid milk shelf life. J. Dairy Sci. 89(E Suppl.):E15E19.
Berry, D. P., B. O'Brien, E. J. O'Callaghan, K. O. Sullivan, and W. J. Meaney. 2006. Temporal trends in bulk tank somatic cell count and total bacterial count in Irish dairy herds during the past decade. J. Dairy Sci. 89:4083-4093.

Boor, K. J., D. P. Brown, S. C. Murphy, S. M. Kozlowski, and D. K. Bander. 1998. Microbiological and chemical quality of raw milk in New York State. J. Dairy Sci. 81:1743-1748.

CDC (Canadian Dairy Commission). 2008. http://www.dairyinfo. gc.ca/pdf/count06.pdf Accessed June 24, 2009.

Chambers, J. V. 2002. The microbiology of raw milk. Pages 39-90 in Dairy Microbiology Handbook. 3rd ed. R. K. Robinson, ed. John Wiley \& Sons Inc., New York, NY.

Flowers, R. S., W. Andrews, C. W. Donnelly, and E. Koenig. 1992. Pathogens in milk and milk products. Pages 103-212 in Standard Methods for the Examination of Dairy Products. 16th ed. R.T. Marshall, ed. American Public Health Association, Washington, DC

Helgren, J. M., and D. J. Reinemann. 2003. Survey of milk quality on United States dairy farms utilizing automatic milking systems. ASAE Paper 033016 in Proc. ASAE 2003 Annu. Int. Mtg., ASAE, St. Joseph, MI.

Jayarao, B. M., S. C. Donaldson, B. A. Straley, A. A. Sawant, N. V. Hegde, and J. L. Brown. 2006. A survey of foodborne pathogens in bulk tank milk and raw milk consumption among farm families in Pennsylvania. J. Dairy Sci. 89:2451-2458.

Jayarao, B. M., S. R. Pillai, A. A. Sawant, D. R. Wolfgang, and N. V. Hegde. 2004. Guidelines for monitoring bulk tank milk somatic cell count and bacterial counts. J. Dairy Sci. 87:3561-3573.

Jayarao, B. M., and D. R. Wolfgang. 2003. Bulk-tank milk analysis. A useful tool for improving milk quality and herd udder health. Pages 75-92 in Update on Bovine Mastitis, Vet. Clin. N. Am. Food Anim. Pract. Vol. 19. P. M. Sears and D. J. Wilson, ed. W. B. Saunders Co., Philadelphia, PA.

Jones, G. M., and S. Sumner. 1999. Testing bulk tank milk samples. Publication no. 404-405, Virginia Coop. Ext., Virginia Tech, Blacksburg, VA.

Jones, M. R., C. L. Williams, and S. B. Thomas. 1971. The effect of seasonal variation and conditions of milk production on the bacteriological quality of refrigerated farm vat milk supplies. Int. J. Dairy Technol. 24:100-105.

Keefe, G., and A. Elmoslemany. 2007. Consumer acceptance of fluid milk after raw milk selection using bulk tank bacteriologic and somatic cell count criteria. Pages 218-219 in Natl. Mastitis Counc. Annu. Mtg. Proc., San Antonio, TX. Natl. Mastitis Counc. Inc., Madison, WI.

Ma, Y., C. Ryan, D. M. Barbano, D. M. Galton, M. A. Rudan, and K. J. Boor. 2000. Effects of somatic cell count on quality and shelf-life of pasteurized fluid milk. J. Dairy Sci. 83:264-274.

Murphy, S. C. 1997. Raw milk bacteria tests: Standard plate count, preliminary incubation count, lab, pasteurization count and coliform count. What do they mean for your farm? Pages 34-41 in Natl. Mastitis Counc. Reg. Mtg. Proc., Syracuse, NY. Natl. Mastitis Counc. Inc., Madison, WI.

Olde Riekerink, R. G., H. W. Barkema, S. Veenstra, D. E. Poole, R. T. Dingwell, and G. P. Keefe. 2006. Prevalence of contagious mastitis pathogens in bulk tank milk in Prince Edward Island. Can. Vet. J. $47: 567-572$.

Østerås, O., and L. Sølverød. 2005. Mastitis control systems: The Norwegian experience. Pages 91-101 in Proc. 4th Int. Dairy Fed. Int. Mast. Conf. H. Hogeveen, ed. Wageningen Acad. Publ., Wageningen, the Netherlands.

Peeler, T. J., J. W. Messer, R. L. Sanders, and H. K. Bachelor. 1989. A comparison of preliminary incubation counts and standard plate counts of grade A bulk tank milk from eleven states. Dairy Food Environ. Sanit. 9:494-497.

Richardson, G. H. 1985. Standard Methods for the Examination of Dairy Products. 15th ed. Am. Public Health Assoc., Washington, DC

Ruegg, P. L., and D. J. Reinemann. 2002. Milk quality and mastitis tests. Bov. Pract. 36:41-54. 
Sargeant, J. M., Y. H. Schukken, and K. E. Leslie. 1998. Ontario bulk milk somatic cell count reduction program: Progress and outlook. J. Dairy Sci. 81:1545-1554.

Schukken, Y. H., K. E. Leslie, A. J. Weersink, and S. W. Martin. 1992. Ontario bulk milk somatic cell count reduction program. 2. Impact on somatic cell counts and milk quality. J. Dairy Sci. 75:3352-3358.

Soler, A., C. Ponsell, M. De Paz, and M. Nuñez. 1995. The microbiological quality of milk produced in the Balearic Islands. Int. Dairy J. 5:69-74.

Sørhaug, T., and L. Stepaniak. 1997. Psychrotrophs and their enzymes in milk and dairy products quality aspects. Trends Food Sci. Technol. 8:35-40.
StataCorp. 2007. Stata Statistical Software: Release 10. StataCorp LP. College Station, TX.

Van Schaik, G., M. Lotem, and Y. H. Schukken. 2002. Trends in somatic cell counts, bacterial counts, and antibiotic residue violations in New York State during 1999-2000. J. Dairy Sci. 85:782-789.

Villar, A., J. A. Garcíaa, L. Iglesiasa, M. L. Garcíab, and A. Oterob. 1996. Application of principal component analysis to the study of microbial populations in refrigerated raw milk from farms. Int. Dairy J. 6:937-945.

Wehr, H. M., and J. H. Frank. 2004. Standard Methods for the Examination of Dairy Products. 17th ed. American Public Health Association, New York, NY. 